\title{
DETERMINAN HARGA SAMURAI BONDS: PENGALAMAN INDONESIA
}

\author{
Nicodemus Simu \\ Institute Perbanas, Jakarta \\ email : nicosimu@perbanas.id
}

\begin{abstract}
ABSTRAK
Tulisan ini bertujuan untuk menentukan dampak berbagai variabel makroekonomi terhadap harga obligasi Republik Indonesia berdenominasi Yen. Objek penelitian adalah obligasi pemerintah Indonesia berdenominasi Yen Jepang. Variabel yang digunakan dalam penelitian ini adalah harga Obligasi Samurai seri RIJPY071 sebagai variabel dependen, sedangkan variabel prediktor adalah tingkat inflasi Jepang, nilai tukar US\$/JP¥, dan suku bunga Jepang. Data yang digunakan dalam penelitian ini adalah data bulanan dari periode Januari 2010 sampai Agustus 2015 dan alat analisis yang digunakan adalah regresi linier berganda. Penelitian ini menyimpulkan bahwa tingkat inflasi memiliki pengaruh positif pada harga obligasi, sementara variabel nilai tukar US\$/JP¥ dan suku bunga masing-masing memberikan dampak negatif pada harga obligasi.
\end{abstract}

Kata Kunci: tingkat inflasi, nilai tukar, suku bunga, harga obligasi samurai

\begin{abstract}
This paper aim is to determine the impact of several macroeconomic variables on bond prices. The object of research is the Republic of Indonesia's bonds denominated in Japanese Yen. Variables used in this research are the price of Samurai Bonds series RIJPY071 as the dependent variable, while the predictor variables are the level of Japanese inflation, exchange rate US\$/JP¥ and Japanese interest rates. The data used in the research are monthly data from the period of January 2010 to August 2015 and the analysis tool used is multiple linear regression. The research concluded that the inflation rate has a positive influence on bond prices, both the exchange rate US\$JPP $¥$ and the interest rates has a negative impact on bond prices.
\end{abstract}

Keywords: inflation rate, exchange rate, interest rate, samurai bonds price.

\section{LATAR BELAKANG}

Pembangunan nasional membutuhkan dana yang dapat dipenuhi dari sumber penerimaan dalam negeri dan juga luar negeri. Sumber-sumber penerimaan di dalam negeri antara lain penerimaan perpajakan dan penerimaan negara bukan pajak. Penerimaan luar negeri digunakan untuk menutup defisit anggaran dan dapat dilakukan dengan beberapa skema. Skema pertama adalah melalui pinjaman bilateral antar negara ataupun pinjaman kepada lembaga keuangan internasional, seperti World Bank, International Monetary Fund, Asian Development Bank, dan lembaga sejenisnya. Skema yang lain dilakukan melalui penerbitan obligasi pemerintah di pasar luar negeri dengan denominasi mata uang di negara penerbitan tersebut.

Pertimbangan untuk menjual obligasi di luar negeri tergantung pada potensi dana yang akan diperoleh dan tidak bergantung kepada kekuatan ekonomi negara yang akan mengeluarkan obligasi tersebut.Argumentasinya adalah bahwa pasar obligasi pemerintah yang efisien dan berfungsi dengan baik dapat membantu kelancaran fungsi pasar keuangan secara umum (Bai et al., 2013). Banyak negara Uni Eropa, yang secara ekonomi dapat dikatakan kuat, juga menjual obligasi berdenominasi valuta asing (Habib dan Ziegler, 2007). Hasil penelitian berbeda oleh Claessen et al. (2003) menyatakan bahwa negara dengan ekonomi kecil lebih mengandalkan obligasi berdenominasi asing, sementara negara yang memiliki framework institusi dan fundamental makro ekonomi yang kuat dapat meningkatkan kemampuan negara menerbitkan obligasi denominasi valuta asing.

Obligasi yang diterbitkan pemerintah Republik Indonesia terdiri dari obligasi dalam mata uang rupiah dan juga valuta asing. Obligasi pemerintah ini juga diterbitkan serta diperdagangkan di dalam negeri (onshore)maupun di luar negeri (offshore). Salah satu obligasi berdenominasi valuta asing yang dimiliki pemerintah Republik Indonesia adalah Samurai bonds. Samurai bondsadalah obligasi dalam denominasi mata uang yen yang diterbitkan oleh penerbit obligasi dari suatu negara di luar Jepang dan diperdagangkan dengan mengacu pada regulasi di pasar Jepang (Packer dan Reynolds, 1997). Pemerintah Indonesia pertama kali menerbitkan Samurai Bonds pada 17 Juli 2009 dengan seri RIJPY0719, berjangka waktu 10 tahun, dengan kupon sebesar $2,73 \%$. 
Obligasi Republik Indonesia yang pertama kali diterbitkan dengan denominasi yen adalah Samurai Bondsseri RIJPY0719 dan diterbitkan berdasarkan beberapa pertimbangan. Pertama, yield yang dijanjikan kepada para investor lebih murah dibandingkan dengan yieldinternational bond yang pernah diterbitkan pemerintah. Sebagai perbandingan, SUN (Surat Utang Negara) pada 2009 dengan tenor 10 tahun menjanjikan yield sebesar 10,42\%, sementara Samurai Bonds seri RIJPY0719 dengan tenor yang sama menjanjikan yield sebesar 2,73\%. Suatu perbedaan yield yang luar biasa besar. Kedua, penerbitan Samurai Bonds ditujukan untuk membayar utang yen yang akan jatuh tempo. Alasan kedua ini sejalan dengan yang disampaikan oleh Habib dan Joy (2008), yang menyatakan bahwa the issuer's desire to ensure its financial obligations are in currencies that match the currencies of its cash infows.

Ketika suatu negara memutuskan untuk menerbitkan obligasi berdenominasi mata uang asing (foreign-currency-denominated bonds), yaitu obligasi yang diterbitkan di dalam mata uang selain mata uang negara penerbit obligasi, salah satu pertimbangannya adalah mata uang tersebut lebih kuat dan lebih stabil dibandingkan mata uang negaranya. Keloharju (2001) menyatakan bahwa terdapat 3 (tiga) alasan diadakannya utang dengan denominasi valuta asing, yaitu hedging, biaya penerbitan atau biaya emisi, dan motif spekulasi. Di sisi lain, Habib dan Joy (2008) menyatakan argumentasi utang dengan denominasi valuta asing adalah agar terdapat keseimbangan antara penerimaan dan pengeluaran negara terhadap suatu valuta asing tertentu, pasar yang lebih luas dan lebih likuid, perbedaan tingkat pajak dan tingkat bunga antar negara. Alasan lain adalah obligasi dalam valuta asing juga untuk lindung nilai terhadap risiko nilai tukar (Packer dan Reynolds, 1997). Likuiditas yang tinggi di pasar obligasi pemerintah dapat memperlancar posisi untuk lindung nilai dan juga memfasilitasi perdagangan pasar sekunder (Bai et al, 2013).

Dari perspektif investor, pertimbangan untuk ikut serta di dalam perdagangan obligasi bergantung pada berbagai faktor. Dalam konteks obligasi berdenominasi valas, pertimbangan tersebut terutama dikaitkan dengan kondisi makro ekonomi dengan indikatorindikator pengukurannya, baik di negara penerbit obligasi maupun negara tempat obligasi tersebut diperdagangkan. Secara umum, nilai obligasi dipengaruhi oleh berbagai macam faktor, antara lain nilai tukar mata uang dan tingkat inflasi, tingkat suku bunga, serta berbagai faktor lain, termasuk juga perilaku investor di dalam melakukan investasi.

Tujuan dari penelitian ini adalah untuk mengetahui pengaruh beberapa variabel makro ekonomi Jepang terhadap pergerakan harga Samurai Bonds seri RIJPY0719. Penerbitan obligasi berdenominasi valuta asing bermanfaat sebagai sarana lindung nilai terhadap risiko gejolak perubahan nilai tukar, oleh karena itu perlu ditelaah keterkaitan antara pergerakan nilai tukar terhadap pergerakan Samurai Bonds Republik Indonesia. Inflasi dan tingkat bunga juga seringkali dikaitkan dengan obligasi (Sitorus, 2015). Selain itu, analisis perlu juga dilakukan untuk mempertegas keterkaitan antara tingkat inflasi dan tingkat bunga di Jepang terhadap harga Samurai Bonds Republik Indonesia.

Obligasi adalah surat utang yang diterbitkan oleh pemerintah atau perusahaan untuk mendapatkan dana. Pihak penerbit obligasi akan membayarkan sejumlah bunga atau sering juga disebut sebagai coupon, kemudian pada tanggal jatuh tempo, utang pokoknya akan dikembalikan kepada pemegang obligasi tersebut (Zubir, 2012). Selain itu, Sitorus (2015) menyatakan bahwa obligasi merupakan surat berharga berjangka waktu menengah dan panjang, yang merupakan bukti pengakuan utang dari penerbit dan dapat diperjualbelikan.

Salah satu jenis obligasi adalah obligasi pemerintah yaitu surat utang pemerintah kepada pihak lain yang akan digunakan untuk mendanai pembangunan. Sejauh ini, obligasi pemerintah merupakan bagian terbesar dalam pasar utang, surat berharga paling likuid, dan dianggap tidak mungkin gagal bayar karena dijamin pembayarannya oleh pemerintah (Zubir, 2012). Menurut denominasi mata uangnya, obligasi yang diterbitkan pemerintah dapat dikelompokkan ke dalam dua kelompok, yaitu obligasi negara berdenominasi rupiah dan obligasi negara berdenominasi valuta asing. Penerbitan obligasi ini juga sering digunakan sebagai suatu sarana lindung nilai terhadap risiko gejolak perubahan nilai tukar. Beberapa contoh obligasi berdenominasi valuta asing antara lain Obligasi Eurodollar (denominasi USD), Obligasi Kangguru (denominasi dolar Australia), Obligasi Maple (denominasi dolar Kanada), dan Obligasi Samurai (denominasi yen). Obligasi samurai atau Samurai Bonds adalah obligasi yang diterbitkan di Tokyo oleh perusahaan nonJepang dan tunduk pada peraturan Jepang (Packer dan Reynolds, 1997).

Pada umumnya, harga obligasi dinyatakan dalam persentase (\%), yaitu persentasi dari nominal. Sitorus (2015) menyatakan terdapat tiga kemungkinan harga 
dari surat utang yang ditawarkan di pasar, yaitu sama dengan nilai nominal (at par), lebih tinggi dari harga nominal (at premium), dan lebih rendah dari harga nominal (at discount). Bagi pemodal, harga obligasi bukanlah satu-satunya faktor yang menentukan apakah obligasi tertentu menarik atau tidak, karena kenaikan harga tidak mencerminkan keseluruhan keuntungan yang akan diperoleh. Kenaikan harga memberikan capital gain bagi pemodal, akan tetapi hasil utama yang paling banyak diharapkan pemodal adalah kupon yang diterima secara reguler. Total pendapatan yang diterima pemodal dari investasi efek obligasi disebut sebagai imbal hasil atau yield, biasanya dinyatakan dalam persen. Terdapat beberapa konsep imbal hasil sebagai alat ukur yang lazim digunakan oleh pelaku pasar obligasi, yaitu current yield, yield to maturity, dan yield to call (Gitman dan Zutter, 2015).

Inflasi adalah kecenderungan dari harga-harga untuk naik secara umum dan terus menerus. Kenaikan harga dari satu atau dua barang saja tidak disebut inflasi, kecuali kenaikan tersebut meluas kepada sebagian besar dari harga barang-barang lain (Boediono, 2005). Indikator yang sering digunakan untuk mengukur tingkat inflasi adalah Indeks Harga Konsumen (IHK). IHK adalah indeks yang mengukur harga rata-rata dari barang dan jasa yang dikonsumsi oleh rumah tangga yang nantinya berpengaruh terhadap pasar saham atau pasar modal (Geetha et al, 2011).

Risiko inflasi terhadap obligasi tidak dapat diabaikan karena inflasi dapat menurunkan daya beli obligasi (Chee dan Fah, 2013). Sama halnya dengan komoditas atau instrumen keuangan yang lain, terjadinya inflasi akan mempengaruhi harga. Kondisi ini akhirnya akan berdampak kuantitas barang atau instrumen yang diminta. Hasil penelitian Ichsan et al (2013) menemukan bahwa inflasi berpengaruh positif terhadap obligasi pemerintah di Indonesia. Demikian pula penelitian yang dilakukan oleh Hsing (2015) yang menyatakan bahwa obligasi pemerintah memiliki hubungan positif dengan inflasi. Hal ini berbeda dengan penelitian sebelumnya yang hasilnya menyatakan inflasi tidak berpengaruh signifikan terhadap harga obligasi pemerintah Indonesia (Sukanto, 2009). H1: Tingkat inflasi berpengaruh terhadap harga samurai bonds pemerintah Indonesia

Samuelson dan Nordhaus (1998) menyatakan bahwa suku bunga adalah pembayaran yang dilakukan atas penggunaan sejumlah uang. Menurut Lipsey et al. (1999), suku bunga adalah harga yang dibayarkan untuk satuan mata uang yang dipinjam pada periode waktu tertentu dan dapat dibedakan menjadi dua yaitu suku bunga nominal dan suku bunga riil. Suku bunga nominal adalah rasio antara jumlah uang yang dibayarkan kembali dengan jumlah uang yang dipinjam, sedangkan adalah suku bunga riil selisih antara suku bunga nominal dengan laju inflasi dan lebih menekankan pada rasio daya beli uang yang dibayarkan kembali terhadap daya beli uang yang dipinjam.

Umumnya, faktor penentu tingkat suku bunga yang berlaku di suatu negara dapat dikelompokkan ke dalam 2 (dua) faktor, yaitu faktor internal danfaktoreksternal. Faktor internal bersumber dari variabel makro ekonomi dalam negeri, sementara faktor eksternal bersumber dari berbagai hal yang terjadi dari luar negeri. Faktor internal meliputi pendapatan nasional, jumlah uang beredar, dan proyeksi tingkat Inflasi. Sedangkan faktor eksternal biasanya terdiri dari rata-rata suku bunga luar negeri dan tingkat kecenderungan perubahan nilai tukar valuta asing.

Kebijakan moneter berpengaruh terhadap perkembangan harga-harga aset lain, baik aset finansial seperti obligasi dan saham, maupun harga aset fisik khususnya aset properti dan emas (Fitriana dan Rohayati, 2013). Besarnya kas yang diterima oleh pemegang obligasi, di samping pengaruh dari size dan timing-nya, tergantung pada tingkat bunga yang berlaku dan berubah sejalan dengan perubahan tingkat inflasi (Zaremba, 2015). Sebagai salah satu instrumen moneter, pergerakan suku bunga akan mempengaruhi harga obligasi. Antwerpen et al (2004) menyatakan bahwa tingkat suku bunga (baik rendah maupun tinggi) berpengaruh terhadap bond maturity, yang kemudian berpengaruh terhadap harga obligasi. Sementara itu, penelitian yang dilakukan oleh Fitriana dan Rohayati (2013) menemukan bahwa tingkat bunga berpengaruh negatif terhadap harga obligasi. Berdasarkan konsep dan temuan empiris tersebut, maka hipotesis 2 adalah: $\mathrm{H} 2$ : Tingkat suku bunga berpengaruh terhadap harga samurai bonds Pemerintah Indonesia

Nilai tukar yang digunakan dalam penelitian ini adalah nilai tukar mata uang yen terhadap dollar US (USD). Pada penelitian obligasi pemerintah Indonesia di Indonesia, Nilai tukar tidak berpengaruh terhadap nilai obligasi karena adanya intervensi dari pemerintah. Salah satu alasan yang dapat disebutkan bahwa tidak adanya pengaruh nilai tukar terhadap nilai obligasi karena pada saat tersebut bank sentral melakukan intervensi. Melemahnya nilai tukar rupiah akan memicu inflasi, apabila inflasi meningkat maka pemerintah akan menaikkan suku bunga Sertifikat Bank Indonesia (SBI). Tingkat suku bunga SBI yang 
tinggi akan menyebabkan yield obligasi menjadi naik sedangkan harga obligasi menjadi turun (Ichsan et al, 2013).

Penelitian yang menghasilkan kesimpulan yang berbeda yang dilakukan oleh Haryanto (2013) dan Sukanto (2009). Temuan kedua peneliti menyimpulkan bahwa kurs berpengaruh negatif signifikan terhadap harga obligasi pemerintah Indonesia. Penelitian yang dilakukan oleh Chee dan Fah (2013) di Inggris menemukan bahwa nilai tukar memiliki hubungan positif dan signifikan terhadap obligasi pemerintah. Pengaruh signifikan nilai tukar terhadap harga obligasi juga terjadi di Spanyol namun hubungan antara keduanya bersifat negatif (Hsing, 2015).

Ogawa dan Shimizu (2004) yang menganalisis keuntungan dan kerugian pemilihan mata uang untuk menerbitkan obligasi internasional menemukan bahwa adanya trade off dari penerbit obligasi antara risiko nilai tukar dan likuiditas dalam pemilihan denominasi kurs dari terbitan obligasi di Asia Timur. Di dalam hal ini, risiko nilai tukar terjadi sejalan dengan membaiknya pasar obligasi regional. Lebih lanjut, di dalam penelitian ini juga ditemukan bahwa risiko nilai tukar lebih kecil dalam hal menerbitkan obligasi dalam mata uang dolar. Berdasarkan konsep dan temuan empiris tersebut, maka hipotesis 3 adalah: H3: Nilai tukar berpengaruh terhadap harga samurai bonds pemerintah Indonesia.

\section{METODE PENELITIAN}

Penelitian ini menggunakan metode penelitian asosiatif kuantitatif. Penelitian ini difokuskan pada Samurai Bonds Republik Indonesia yang diterbitkan dan dipasarkan di negara Jepang, sementara sampel penelitian adalah obligasi yang pertama kali diterbitkan, yaitu Samurai Bondsseri RIJPY0719 dan pertama kali diterbitkan pada 17 Juli 2009. Variabel dependen di dalam penelitian ini adalah Harga Samurai Bonds Seri RIJPY0719, sementara variabel independen terdiri dari Nilai tukar Dolar terhadap Yen, Tingkat Inflasi Jepang, dan Tingkat Suku Bunga Jepang.

Jenis data yang digunakan di dalam penelitian ini terdiri dari data yang terkait dengan Samurai Bonds seri RIJPY0719 yang diperdagangkan di pasar sekunder bursa Nikkei, dan diperoleh dari berbagai sumber, antaralain, www.inflation.eu, https:/ /www.boj.or.jp/en, www.x-rates.com, dan www. bloomberg.com. Data-data yang dimaksud adalah data-data pada periode Januari 2010 sampai dengan Agustus 2015, antara lain data mengenai pergerakan harga Samurai Bonds seri RIJPY0719, tingkat inflasi di Jepang, kurs US\$/JP¥, dan tingkat bunga di Jepang.

Definisi operasional masing-masing variabel ditampilkan pada Tabel 1. Teknik analisis data yang digunakan dalam penelitian ini adalah analisis regresi linier berganda (multiple regression model). Selain itu, juga akan dilakukan pengujian hipotesis untuk melihat pengaruh masing-masing variabel independen terhadap variabel dependen, dan selanjutnya juga akan dilakukan pengujian goodness of fit untuk melihat apakah model regresi layak digunakan. Pengujian hipotesis akan dilakukan dengan menggunakan uji-t ( $t$-test), sementara pengujian goodness of fit akan menggunakan uji-F $(F$-test). Pengujian untuk mengukur kemampuan variabel independen di dalam mempengaruhi variabel dependennya atau mengukur besarnya kontribusi

Tabel 1. Operasionalisasi Variabel

\begin{tabular}{|c|c|c|}
\hline Variabel & $\begin{array}{r}\text { Konsep Variabel } \\
\end{array}$ & Ukuran \\
\hline $\begin{array}{l}\text { Harga } \\
\text { Samurai } \\
\text { Bonds Seri } \\
\text { RIJPY0719 }\end{array}$ & $\begin{array}{l}\text { Harga obligasi pemerintah Indonesia } \\
\text { berdenominasi Yen yang diperdagangkan } \\
\text { di pasar modal Jepang }\end{array}$ & $\begin{array}{l}\text { Rata-rata harga Samurai Bonds pada } \\
\text { closing date harian yang dinyatakan } \\
\text { di dalam satuan persentase }\end{array}$ \\
\hline $\begin{array}{l}\text { Tingkat } \\
\text { Inflasi Jepang }\end{array}$ & $\begin{array}{l}\text { Meningkatnya harga-harga secara umum } \\
\text { dan terus-menerus }\end{array}$ & $\begin{array}{l}\text { Tingkat inflasi rata-rata bulanan di } \\
\text { Jepang yang dinyatakan di dalam } \\
\text { satuan persentase }\end{array}$ \\
\hline $\begin{array}{l}\text { Nilai Tukar } \\
\text { Dolar } \\
\text { Terhadap Yen }\end{array}$ & $\begin{array}{l}\text { Harga suatu mata uang terhadap mata uang } \\
\text { yang lain. Di dalam penelitian ini } \\
\text { digunakan nilai tukar dollar AS terhadap } \\
\text { Yen Jepang. }\end{array}$ & $\begin{array}{l}\text { Kurs tengah rata-rata setiap bulan } \\
\text { transaksi dinyatakan di dalam satuan } \\
\$ / ¥\end{array}$ \\
\hline $\begin{array}{l}\text { Tingkat } \\
\text { bunga Jepang }\end{array}$ & $\begin{array}{l}\text { Long-term prime lending rate, yaitu } \\
\text { tingkat suku bunga bank komersialrata-rata } \\
\text { yang berlaku di Jepang yang dibebankan } \\
\text { kepada nasabah prioritas. }\end{array}$ & $\begin{array}{l}\text { Tingkat suku bunga rata-rata bulanan } \\
\text { di Jepang, dinyatakan di dalam } \\
\text { satuan persentase }\end{array}$ \\
\hline
\end{tabular}


variabel independen terhadap variasi variabel dependen menggunakan koefisien determinasi, yaitu koefisien determinasi yang disesuaikan atau Adjusted R Square.

\section{HASIL DAN PEMBAHASAN}

Statistik deskriptif untuk menggambarkan datadata yang berkaitan dengan variabel-variabel yang dianalisis ditunjukkan pada Tabel 2 berikut.

Tabel 2. Statistik Deskriptif Harga Samurai Bonds, Tingkat Inflasi Jepang, Nilai Tukar US\$/JP¥,Tingkat Bunga Jepang

\begin{tabular}{lrrrrr}
\hline & N & \multicolumn{1}{c}{ Minimum } & Maximum & \multicolumn{1}{c}{ Mean } & \multicolumn{1}{c}{ Std. Deviation } \\
\hline Bond_Price & 68 & 95,416 & 112,710 & 106,94462 & 3,536387 \\
Inflation_Rate & 68 & $-1,09$ & 3,71 &, 4938 & 1,33313 \\
USD_Y & 68 & 76,600 & 124,150 & 93,80824 & 14,462204 \\
Interest_Rate & 68 & 1,100 & 1,700 & 1,31397 &, 172308 \\
Valid N(listwise) & 68 & & & & \\
\hline
\end{tabular}

Sumber: Hasil pengolahan data penelitian

Dari Tabel 2 terlihat jelas bahwa besaran harga Samurai Bonds Republik Indonesia seri RIJPY0719 bervariasi pada kisaran harga terendah di posisi 95,42 dan harga tertinggi pada posisi sebesar 112,71. Harga terendah tersebut terjadi pada Februari 2010, sementara harga tertinggi terjadi pada April 2011. Memperhatikan perkembangan harga obligasi ini secara detail, sampai dengan kuartal ketiga 2010, pergerakan harga obligasi Republik Indonesia cenderung berat dan bahkan bergerak pada area negatif di bawah angka 100. Hal ini dapat dijadikan indikasi bahwa investor Jepang masih belum percaya sepenuhnya pada reputasi Indonesia sebagai negara yang berdaulat untuk dapat mengembalikan pinjamannya. Selanjutnya pada tingkat inflasi terlihat bahwa kisaran nilai minimum tingkat inflasi adalah sebesar $-1,09 \%$ dan nilai maksimumnya sebesar $3,71 \%$. Besarnya mean yang mendekati 0 menunjukkan bahwa selama kurun waktu penelitian, ternyata di Jepang lebih banyak mengalami deflasi dibandingkan dengan inflasi. Perlu dicatat pula bahwa selama periode bulan April-September 2014, besaran tingkat inflasi yang terjadi merupakan tingkat inflasi tertinggi di Jepang di dalam kurun waktu penelitian.

Sementara itu, kurs US\$/JP¥, berada pada kisaran $¥ 76,6$ sampai dengan $¥ 124,15$ untuk setiap dolar. Hal ini menunjukkan bahwa posisi termahal nilai tukar Dolar AS terhadap Yen Jepang adalah $¥ 76,60$ dan terjadi pada Oktober 2011 dan termurah pada posisi $¥ 124,15$ pada Mei 2015. Rata-rata nilai tukar Dolar AS terhadap Yen Jepang selama periode tersebut adalah $¥ 93,81$. Dengan memperhatikan perkembangan nilai tukar pada tabel tersebut, terlihat bahwa sejak Februari 2013, pemerintah Jepang sengaja mengambil kebijakan untuk mempertahankan nilai tukar Yen yang rendah dan kebijakan ini terlihat terus berlanjut sampai dengan saat ini. Kisaran tingkat bunga Jepang berada pada level 1,1\% sampai dengan $1,7 \%$. Besaran tingkat bunga tertinggi tersebut terjadi pada pada April 2011 dan kemudian secara konstan terus menurun sampai ke angka 1,1\% pada Agustus 2015.

Uji asumsi klasik dilakukansebagai prasyarat penggunaan model regresi linier berganda yang mengharuskan bahwa model regresi akan dapat dijadikan alat estimasi yang tidak bias jika telah memenuhi persyaratan BLUE (best linear unbiased estimator). Hasil menunjukkan bahwa model layak dan telah lolos semua uji yang meliputi uji normalitas, multikolinearitas, heteroskedastisitas, dan autokorelasi. Hasil persamaan regresi ditunjukkan pada Tabel 3.

Dari Tabel 3 maka dapat disusun persamaan regresi linier berganda sebagai berikut:

PRICE $=123,952+0,552$ INF-0,016 KURS-12,011 INT Di mana:

PRICE: Harga Samurai Bonds RIJPY0719

INF : Tingkat inflasi Jepang

KURS : Nilai tukar US\$/JP¥

INT : Tingkat bunga Pinjaman Jepang

Berdasarkan persamaan di atas dapat diketahui bahwa inflasi berpengaruh positif terhadap harga Samurai Bonds Republik Indonesia, yang berarti kenaikan tingkat inflasi akan meningkatkan harga obligasi RIJPY0719. Di dalam konteks ini, setiap kenaikan satu persen pada tingkat inflasi akan meningkatkan harga obligasi sebesar $0,552 \%$. Sementara itu, kondisi sebaliknya terjadi pada kurs dan tingkat bunga Jepang. Kedua variabel makro ekonomi ini masing-masing berpengaruh negatif terhadap harga Samurai Bonds Republik Indonesia, dalam arti setiap kenaikan kurs dan tingkat bunga Jepang akan menurunkan harga obligasi RIJPY0719. Jika dikaitkan dengan besaran koefisien variabel, persamaan regresi tersebut menunjukkan bahwa setiap kenaikan kurs sebesar ¥1 akan 
Tabel 3. Hasil Regresi Linier Berganda

\begin{tabular}{llrrrrr}
\hline & & \multicolumn{2}{c}{ Unstandardized } & \multicolumn{2}{c}{$\begin{array}{c}\text { Standardized } \\
\text { Model }\end{array}$} & \multicolumn{2}{c}{ Coefficients } & Coefficients & & \\
\cline { 3 - 6 } & & \multicolumn{1}{c}{ Std. Error } & Beta & & t \\
\hline 1 & (Constant) & 123,952 & 5,376 & &,- 628 &, 532 \\
& Inflation_Rate &, 552 &, 320 &, 208 & $-2,455$ &, 017 \\
& USD_Y &,- 016 &, 031 &,- 065 & $-2,711$ &, 009 \\
& Interest_Rate & $-12,011$ & 2,593 &,- 585 & 6,360 &, 000 \\
\hline
\end{tabular}

a. Dependent Variable: Bond_Price

Sumber: Hasil pengolahan data penelitian

menurunkan harga obligasi sebesar $0,016 \%$ dan setiap kenaikan tingkat inflasi sebesar $1 \%$ akan menurunkan harga obligasi sebesar 12,011\%. Kesemua perubahan pada setiap variabel independen ini berlaku dengan asumsi bahwa semua variabel independen lain tidak berubah.
Uji kelayakan model (Uji Goodness of fit) digunakan untuk menguji apakah model yang diperoleh dari penelitian ini layak atau tidak untuk melakukan fungsi prediksi. Pengujian kelayakan model dilakukan dengan menggunakan uji F. Tabel 4 berikut menunjukkan hasil uji ANOVA sebagai berikut

Tabel 4. Uji ANOVA

\begin{tabular}{llrrrrr}
\hline Model & & Sum of Squares & Df & Mean Square & F & \multicolumn{1}{c}{ Sig. } \\
\hline 1 & Regression &, 003 & 3 &, 001 & 64,354 &, $000^{\mathrm{b}}$ \\
& Residual &, 001 & 64 &, 000 & & \\
& Total &, 004 & 67 & & & \\
\hline
\end{tabular}

a. Dependent Variable: Bond_Price

b. Predictors: (Constant), Inflation_rate, USD_Y, Interest_Rate,

Sumber: Hasil pengolahan data penelitian

Dari hasil uji ANOVA pada tabel 4 diperoleh nilai Sig (F-statistic) sebesar 0,000. Dengan menggunakan alpha 0,05, dapat dijelaskan bahwa dikarenakan Sig (F-statistic) lebih kecil dari 0,05 (5\%). Dengan demikian dapat disimpulkan bahwa model layak digunakan dalam kapasitasnya sebagai fungsi prediksi. Selanjutnya koefisien determinasi digunakan untuk menentukan besarnya kontribusi pengaruh variabel independen secara bersama-sama terhadap variabel dependen dan hasil ditunjukkan pada Tabel 5 berikut.

Tabel 5. Koefisien Determinasi

\begin{tabular}{llrrr}
\hline Model & $\mathrm{R}$ & R Square & $\begin{array}{c}\text { Adjusted R } \\
\text { Square }\end{array}$ & $\begin{array}{c}\text { Std. Error of the } \\
\text { Estimate }\end{array}$ \\
\hline 1 &, $867^{\mathrm{a}}$ &, 751 &, 739 &, 00377068 \\
\hline
\end{tabular}

a. Predictors: (Constant), Inflation_Rate, USD_Y, Interest_Rate

b. Dependent Variable: Bond_Price

Sumber: Hasil pengolahan data penelitian

Berdasarkan Tabel 5 terlihat bahwa nilai Adjusted $R^{2}$ adalah adalah sebesar 0.739 atau $73.9 \%$. Besaran koefisien determinasi tersebut menunjukkan bahwa kontribusi pengaruh dari variabel independen, yaitu Tingkat Inflasi Jepang, Nilai Tukar Dolar AS Terhadap Yen, dan Tingkat Bunga Jepang secara bersama-sama terhadap harga obligasi RIJPY0719 adalah sebesar 73.9\%, sedangkan sisanya yaitu sebesar $26.1 \%$ dipengaruhi oleh variabel lain.

Uji-t (t-test) dilakukan untuk mengetahui signifikansi pengaruh masing-masing variabel tingkat inflasi, kurs US\$/JP¥, dan tingkat bunga Jepang terhadap pergerakan harga obligasi RIJPY0719. Mengacu pada Tabel 3 terlihat bahwa besaran nilai Sig untuk variabel tingkat inflasi, kurs US\$/JP¥, , dan tingkat suku bunga masing-masing sebesar 0,017, 0,009, dan 0,000. Nilai Sig masing-masing variabel tersebut berada di bawah alpha $(\alpha=0,05)$ yang mengindikasikan bahwa terdapat pengaruh signifikan masing-masing variabel tingkat inflasi, kurs US $\$ / J P ¥$,dan tingkat suku bunga secara parsial terhadap harga obligasi RIJPY0719.

Inflasi memiliki pengaruh signifikan terhadap obligasi dengan penjelasan bahwa pada saat suku bunga dan inflasi mencapai titik tertinggi, harga 
obligasi diestimasi akan mencapai titik terendah, yang tentunya akan menjadi peluang bagi investor untuk berinvestasi terutama pada obligasi yang memiliki jangka waktu panjang yang memiliki ekspektasi imbal hasil lebih tinggi. Hal ini terjadi karena setelah mencapai titik puncak, suku bunga akan cenderung turun dan memberikan dampak positif bagi pergerakan harga obligasi (Ichsan et al., 2013).

Penelitian ini menyimpulkan adanya pengaruh signifikan tingkat inflasi terhadap harga obligasi yang diperdagangkan di pasar Jepang. Temuan yang menarik dari penelitian ini adalah bahwa ternyata pengaruh tersebut tidak bersifat negatif atau dengan kata lain, penelitian ini menunjukkan bahwa apabila tingkat inflasi bergerak naik, maka harga obligasi juga cenderung bergerak searah dengan pergerakan tingkat inflasi. Hal ini seakan-akan menunjukkan bahwa apabila tingkat inflasi semakin tinggi, maka daya beli masyarakat Jepang juga semakin tinggi sehingga membuat minat beli terhadap obligasi meningkat, dan memaksa terjadinya tekanan beli, dan pada gilirannya membuat harga obligasi bergerak naik.

Fenomena ini kiranya dapat dijelaskan berdasarkan beberapa dengan beberapa argumentasi. Pertama, terjadinya peningkatan tingkat inflasi dengan dampak ikutannya yaitu peningkatan harga secara umum, pada dasarnya akan membuat minat masyarakat Jepang untuk berinvestasi pada Samurai Bonds menurun. Ketika terjadi penurunan minat beli, salah satu strategi yang dapat dipilih adalah meningkatkan besaran yield. Peningkatan yield, selain untuk mendorong kembali minat beli, juga sekaligus sebagai kompensasi yang potensi risiko obligasi. Dengan demikian adanya korelasi yang positif antara besaran inflasi dengan besaran yield. Ingat sekali lagi bahwa, yield akan menentukan besarnya harga obligasi di pasar sekunder. Kenaikan yield kemudian pada gilirannya membuat investor tertarik untuk menanamkan dananya di obligasi sehingga harga obligasi kemudian bergerak naik.

Kedua, selama 68 bulan pengamatan, yaitu periode Januari 2010 sampai dengan Agustus 2015, sejumlah 33 data menunjukkan angka inflasi yang negatif, atau menunjukkan adanya deflasi. Sementara itu, tingkat inflasi positif hanya bergerak pada kisaran angka $0,1 \%-3,71 \%$. Kisaran tingkat inflasi yang positif dan cukup tinggi (2\%-3\%) terjadi pada tahun 2014, tetapi kemudian menurun kembali menjadi di bawah $1 \%$ pada awal 2015. Kiranya secara umum, kisaran inflasi yang rendah dan stabil, apalagi dengan terjadinya deflasi tidak dianggap sebagai faktor yang secara psikologis menurunkan minat investor untuk membeli obligasi. Sebaliknya, terjadinya deflasi menunjukkan bahwa nilai mata uang Yen semakin meningkat sehingga yang terjadi adalah peningkatan minat beli terhadap obligasi, terutama obligasi yang memberikan yield lebih tinggi daripada tingkat bunga pasar. Sinyalemen ini diperkuat pula dengan upaya bank sentral Jepang yang mempertahankan kebijakan tingkat suku bunga mendekati $0 \%$. Kebijakan tingkat suku bunga sebesar 0\%akan berdampak pada seberapa pun besaranyield obligasi dansepanjang besaran yield tersebut berada pada tingkatan yang lebih tinggi dari pada tingkat suku bunga perbankan, obligasi tersebut tetap merupakan instrumen investasi yang menarik.

Mata uang Yen merupakan mata uang yang dianggap sebagai mata uang dengan status safe haven (Botman et al., 2013). Safe haven adalah status dari suatu mata uang kuat yang tidak mudah terpengaruh oleh berbagai gejolak krisis ekonomi domestik, regional, dan global, serta merupakan mata uang yang dipercaya ketika investor global menghindari risiko. Yen sebagai mata uang safe havensejalan dengan kondisi Jepang yang memiliki tingkat bunga relatif rendah dibandingkan tingkat bunga negara-negara lain, net foreign asset yang kuat, serta pasar modal yang likuid dan memiliki fundamental kuat. Poin yang paling penting dengan status Yen sebagai safe haven adalah bahwa investor domestik dan asing akan tetap berinvestasi di pasar Jepang tanpa terpengaruh oleh gejolak nilai tukar dan dengan demikian berarti bahwa, seharusnya harga obligasi juga tidak terpengaruh oleh gejolak nilai tukar karena uang beredar tetap berada di pasar domestik dan dengan mata uang domestik.

Penelitian ini menunjukkan bahwa nilai tukar US $\$ / J P ¥$ berpengaruh terhadap pergerakan harga obligasi. Temuan ini walaupun telah menjawab dan sesuai dengan hipotesis yang diajukan, tetapi pada dasarnya kontradiktif dengan asumsi yang dipercaya mengingat status Yen sebagai mata uang safe haven. Pertentangan ini diperkirakan terjadi karena pada saat terjadi gejolak ekonomi, pembuat kebijakan atau regulator, di dalam hal ini adalah pemerintah Jepang, menghadapi tantangan untuk melakukan stabilitasi atas kemungkinan terjadinya capital flight. Tantangan seperti ini memerlukan waktu dan biaya penyesuaian terhadap ekonomi dan bisa jadi menimbulkan dis-alokasi ekonomi yang bersifat sementara, sebelum akhirnya nilai mata uang negara tersebut kembali stabil (Bussiere et al., 2013).

Nilai tukar US\$/JP¥ berpengaruh negatif terhadap harga obligasi berarti semakin tinggi nilai tukar US\$/JP¥ akan berdampak pada semakin rendahnya harga obligasi. Pada saat nilai tukar berada 
pada tingkat tinggi, maka structure slope dan low term convexity (kurva yield) diprediksi akan tinggi. Pada saat yield obligasi tinggi, secara teoritis akan menyebabkan nilai obligasi turun. Dampak seperti ini berarti bahwa jika nilai tukar US\$/JP¥ meningkat, yang mengindikasikan harga dolar semakin mahal, maka investor diperkirakan akan menahan diri dan berada pada posisi wait and seeuntuk memasuki pasar dan berinvestasi sambil menunggu diundangkannya kebijakan pemerintah dan dampak ikutan dari kebijakan tersebut. Dengan demikian, ketika nilai tukar menjadi pertimbangan penting dalam berinvestasi, maka nilai tukar akan mempengaruhi nilai obligasi (Haryanto, 2013; Sukanto, 2009). Namun ketika pemerintah melakukan intervensi atau respon maka pengaruh tersebut tidak lagi signifikan (Ichsan et al., 2013). Hal ini juga didukung penelitian Ogawa dan Shimizu (2004) yang menyatakan bahwa pasar obligasi lokal berbeda dengan pasar obligasi regional, obligasi dengan mata uang yen Jepang merupakan salah satu mata uang yang dapat menurunkan resiko investor karena efek portofolio dengan mata uang yen Jepang dapat mengurangi risiko nilai tukar.

Tingkat suku bunga merupakan salah satu variabel makro ekonomi yang paling sering dicermati karena mempunyai dampak yang luas bagi perekonomian dan sektor kehidupan masyarakat. Perubahan pada suku bunga akan berdampak sangat besar terhadap sektor ekonomi. Titman et al., (2014) menyatakan the value of bond is inversely related to changes in the market's required yield to maturity atau tingkat suku bunga pasar dan harga obligasi akan bergerak dengan arah yang saling berlawanan. Dengan demikian, apabila tingkat suku bunga pasar naik, maka harga pasar obligasi akan turun, dan sebaliknya, jika suku bunga pasar turun maka harga pasar obligasi akan naik. Singkatnya, suku bunga dengan nilai atau harga suatu instrumen investasi memiliki hubungan yang erat. Suku bunga pasar inilah yang selalu memicu ketidakstabilan (volatility) harga suatu obligasi.

Penelitian ini menemukan bahwa tingkat suku bunga berpengaruh negatif terhadap harga obligasi, yang berarti semakin tinggi tingkat bunga, semakin rendah harga obligasi. Perubahan pada harga obligasi merupakan elemen yang dianggap menghadirkan unsur ketidakpastian bagi investor obligasi. Peningkatan suku bunga menyebabkan pemegang obligasi berpotensi mengalami kerugian nilai pasar. Sebagai dampak dari tidak dapat diprediksinya suku bunga di masa depan dan nilai obligasi yang dihasilkan dari suku bunga tersebut, investor obligasi terpapar dengan risiko perubahan tingkat suku bunga. Hal inilah yang menyebabkan keterkaitan yang tinggi antara tingkat suku bunga dengan nilai atau harga obligasi. Semakin tinggi tingkat suku bunga pada dasarnya menjadi faktor penyebab tinggi yield obligasi. Tingginya yield obligasi secara langsung akan menjadi indikator bahwa obligasi tersebut rentan dengan risiko dan kurang aman dijadikan sebagai instrumen investasi, dengan demikian, sebagai kompensasinya, investor akan memberikan nilai yang rendah bagi obligasi dengan yield yang tinggi.

Dampak dari diadopsinya kebijakan suku bunga nol persen oleh Bank of Japan membuat sebagian besar investor obligasi pemerintah di negara Jepang melakukan investment switching ke instrumen kredit atau investasi yang memberikan yield yang lebih tinggi. Pergeseran ini diduga karena perilaku risk aversion dari investor obligasi Jepang sangat rendah sehingga menyebabkan pelaku pasar modal dan/atau sektor perbankan lebih memilih menjalankan kegiatan reach for yields dibandingkan dengan memperhitungkan risiko dari investasi yang dipilih tersebut (Baba et al, 2005). Selanjutnya disebutkan pula bahwa ketika harga obligasi bergerak naik, dengan catatan bahwa ruang untuk kenaikan tersebut terbatas, kemiringan (skewness) negatif pada harga cenderung terjadi di pasar obligasi. Observasi ini terjadi di lingkungan dengan tingkat suku bunga rendah dan pada hampir semua instrumen investasi dengan tingkat pengembalian tetap (fixed income returns), termasuk Jepang yang mengadopsi kebijakan tingkat suku bunga rendah (Nishioka dan Baba, 2008).

\section{Implikasi Kebijakan}

Trend dasar perkembangan obligasi di Jepang berbeda dengan negara maju lain seperti di Amerika Serikat, karena transaksi di pasar obligasi sekunder kurang aktif dibandingkan dengan di Amerika Serikat. Di Jepang sendiri, peringkat obligasi sangat penting dan obligasi lebih dipilih oleh investor dibanding dengan instrumen kredit khususnya bagi perbankan. Investor di Jepang juga tidak terlalu memperdulikan tingkat risiko, mereka lebih berani mengambil risiko untuk mendapatkan return yang tinggi. Tipe investor yang mengutamakan keuntungan dan tidak memperdulikan risiko menjadi ciri dari investor Jepang (Nishioka dan Baba, 2008). Berdasarkan temuan Nishoka dan Baba (2008), pemerintah Indonesia seyogianya memiliki strategi untuk memperbaiki peringkat obligasi sebagai salah satu hal yang dianggap penting oleh investor Jepang. Selain itu, agar tetap menarik bagi investor Jepang, imbal hasil yang ditawarkan hendaknya dianalisis 
secara mendalam tanpa harus membebani keuangan pemerintah. Dana yang bersumber dari obligasi berdenominasi valuta asing hendaknya ditujukan hanya untuk belanja yang bersifat sangat urgent dan dengan memperbandingkan biaya dan manfaatnya jika dibandingkan dengan instrumen hutang lainnya.

Komposisi investor pemegang obligasi di Jepang tidak terdistribusi dengan seimbang, karena $92 \%$ pemegang obligasi pemerintah di Jepang adalah investor domestik. Dalam menganalisis permintaan obligasi di Jepang sangat penting untuk menganalisis pasar dan kondisi neraca atau kondisi ekonomi, baik pemerintah maupun investor (Ogawa dan Imai, 2014). Dari analisis ini menunjukkan bahwa menerbitkan Samurai Bonds memang sangat potensial untuk mendapatkan dana karena investor domestik di Jepang sangat aktif dalam menanamkan investasi di instrumen obligasi pemerintah dibandingkan dengan obligasi perusahaan (Habib dan Ziegler, 2007). Peminjam asing dapat mengambil keuntungan dari rendahnya suku bunga dan deflasi yang terjadi di Jepang karena akan membuat instrumen obligasi banyak diminati namun biaya yang tinggi dan proses yang membutuhkan waktu lama membuat inefisiensi bila menerbitkan obligasi di Jepang (Park dan Park, 2003).

\section{SIMPULAN}

Berdasarkan analisis pada bagian sebelumnya, penelitian ini menyimpulkan bahwa tingkat inflasi Jepang dan Kurs US\$/JP¥ berpengaruh negatif signifikan terhadap harga obligasi samurai Republik Indonesia. Selain itu, ditemukan pula bahwa tingkat suku bunga Jepang memiliki pengaruh yang positif signifikan terhadap harga Samurai Bonds Republik Indonesia RIJPY0719.

\section{REFERENSI}

Antwerpen V., A Vincent, Janwillem P. Engel, Harry M. Kat, dan Theo P. Kocken. 2004. "Why Investors Should Hold Long-Dated Bonds, Even When Interest Rate Are Low", Working Paper (Online) August 18, (http://www. ssrn.com, accessed on 29 Juli 2016).

Baba, N., Nishioka, S., Oda, N., Shirakawa, M., Ueda, K., and Ugai, H. 2005. Japan's Deflation, Problems in The Financial System and Monetary Policy. Bank of Japan Monetary and Economic Studies, 23, 47-111.

Bai, Jennie, Michael Fleming, dan Casidhe Horan. 2013. The Microstructure of China's Government Bond Market. Federal Reserve Bank of New York Staff Reports, 622.
Boediono. 2005. Ekonomi Moneter. Yogyakarta (ID) : BPFE.

Botman D, Filo IdC, Lam WR. 2013. The Curious Case of the Yen as a Safe Haven Currency: A Forensic Analysis. IMF Working Paper. WP/ $13 / 228$.

Bussière, Matthieu, Claude Lopez and Cédric Tille, 2013, "Currency Crises in Reverse: Do Large Real Exchange Rate Appreciations Matter for Growth?", MPRA Paper No. 44096.

Chee, Soh Wei dan Cheng Fan Fah. 2013. "Macroeconomic Determinants of UK Treasury Bonds Spread", International Journal of Arts and Commerce, Vol. 2 No. 1, 163 - 172.

Claessens, Stijn, Daniela Klingebiel, and Sergio Schmukler. 2003. Government Bonds in Domestic and Foreign Currency: The Role of Macroeconomic and Institutional Factors. [internet]. [downloaded on 6 November 2015]. Available in http://www.researchgate.net/ publication/256726

Fitriana, Eka Sari dan Suci Rohayati. 2013, "Pengaruh Suku Bunga Terhadap Harga Obligasi Melalui Yield Obligasi”, Jurnal Ilmu Manajemen, Volume 1 Nomor 3. 724 - 734.

Geetha C, Mohidin R, Chandran VV, Chong V. 2011. The Relationship between Inflation and Stock Market: Evidence from Malaysia, United States, and China. International Journal of Economics and Management Sciences. 1(2): 1-16.

Gitman, Lawrence J. dan Chad J. Zutter. 2014. "Principles of Managerial Finance", 14ed, Pearson Education Limited. England.

Habib, Maurizio Michael dan Mark Joy. 2008. "Foreign-Currency Bonds: Currency Choice and The Role of Uncovered anda Covered Interest Parity", European Central Bank, Working Paper Series, No. 947.

Habib, Michael A dan Alexandre Ziegler. 2007. "Why Government Bonds are Sold by Auction and Corporate Bonds by Posted-Price Selling", Journal of Financial Intermediation, 16, 343- 367.

Haryanto MA. 2013. Analisis Pengaruh Maturity, Tingkat Suku Bunga SBI, Kurs dan Harga Minyak Dunia terhadap Harga Obligasi Pemerintah [Skripsi]. Semarang (ID): Fakultas Ekonomika dan Bisnis Universitas Diponegoro.

Hsing, Yu. 2015. "Determinants of the Government Bond Yield in Spain: A Loanable Funds Model", International Journal of Financial Studies. Volume 3, 342-350. 
Ichsan, Syamni G, Nurlela dan Rahman A. 2013. "Dampak BI Rate, Tingkat Suku Bunga, Nilai Tukar,dan Inflasi terhadap Nilai Obligasi Pemerintah", Jurnal Keuangan dan Perbankan. 17(2): 310-322.

Keloharju, Matti. 2001. "Why do Firms Raise Foreign Currency Denominated Debt? Evidence from Finland". European Financial Management, Volume 7, No. 4, 481-496.

Nishioka, Shinichi dan Naohiko Baba. 2008. "Risk Taking by Japanese Bond Investors: Testing the "reach for yields" Hypothesis in the Japanese Bond Markets", The Quarterly Review of Economics and Finance, 48, 691 - 707.

Lipsey, Richard G, Paul N Courant, Christoper T S Ragan. 1999. Economics. 12th edition. London: Adwison-Wesley Publishing Company Inc.

Ogawa E, Shimizu J. 2004. "Bond Issuers' Tradeoff for Common Currency Basket Denominated Bonds in East Asia". Journal of Asian Economics, 15, 719-738.

Ogawa, Kazuo dan Kentaro Imai. 2014. "Why Do Commercial banks Hold Government Bonds? The Case of Japan" Journal of The Japanese and International Economics, 34, 201 - 216.

Packer, Frank dan Elisabeth Reynolds. 1997. "The Samurai Bonds Market", Current Issues in Economic and Finance, Federal Reserve Bank of New York, Volume 3, No. 8.
Park, Yung-Chul dan Daekeun Park. 2003. "Creating Regional Bond Markets in East Asia: Rationale and Strategy". The 2nd Annual Conference of PECC Finance Forum. Hua Hin. Thailand. Samuelson, Paul A. dan William D. Nordhaus. 1998, Economics. Boston. Mass Irwin/ McGraw-Hil. Sitorus T. 2015. Pasar Obligasi Indonesia: Teori dan Praktek. Jakarta (ID):Rajawali Press.

Sukanto E. 2009. Pengaruh Suku Bunga Deposito, Kurs Rupiah-USD, Tingkat Inflasi, IHSG dan Volume Transaksi Terhadap Harga Obligasi Pemerintah RI (SUN). Fokus Ekonomi. 4(2), 9-23.

Titman, Sheridan J., Arthur J. Keown, dan John D. Martin. 2014. Financial Management: Principles and Application. Edinburg Gate: Pearson Education Limited.

Widjaja G dan Jono. 2006. Penerbitan Obligasi dan Peran Serta Tanggung Jawab Wali Amanat dalam Pasar Modal. Jakarta (ID): Prenida Media Group.

www.inflation.eu, www.boj.or.jp/en, www.X-rates.com, and www.bloomberg.com

Zaremba, Adam. 2015. "Inflation, Business Cycles, and Commodity Investing in Financialized Markets", Business and Economics Research Journal, Volume 6 Number 1, 1-18.

Zubir Z. 2012. Portofolio Obligasi. Jakarta (ID): Penerbit Salemba Empat. 